\title{
PROLOGUE
}

\section{Along the Big Question Mark}

"Wake up!" I shouted to myself as I shook my head like a soaked dog getting out of water. Refocusing my gaze on the dark road ahead, I tightened my grip on the steering wheel. Just thirty more minutes, I told myself. Stay awake for just thirty more minutes and I can collapse into my bed. It was almost one o' clock in the morning, and I was on my way home from a one-on-one Bible study with Sara, a young migrant in her twenties who was a member of the Brazilian Pentecostal denomination that I was researching. Like most Brazilians in Japan, she was a factory worker with a long shift. On this particular day, her Japanese boss asked her to work three extra hours to meet the daily production quota, which is why she could leave her factory only at nine in the evening.

"Thank you for waiting! My body stunk from sweating, so I had to go home to take a quick shower," Sara said as she bustled into the fast food restaurant where I was waiting close to ten o'clock. We usually met at Saizeriya, a chain restaurant that Sara liked, because it was close to her workplace in Kariya. It was a forty-five-minute drive from Toyota, where I lived during fieldwork. We started the Bible study as she ate her late dinner. "Today we are going to learn about opening our hearts to Jesus," Sara said as she wiped pizza sauce from her fingers. "Now, I'm not sure how you Japanese people think about this, but God knows what you think and how you feel all the time. You understand?"

Realizing that she was waiting for my response after a few seconds, I hesitantly opened my mouth. "Um, do I understand?"

"Yes, do you believe that God is always in your heart?"

"Um ... Sara, you know I'm not Christian, at least not yet. We talked about this."

"Well, but it's God's plan that you chose to study our churches. There is no such thing as coincidence! You want to learn about the Word of God, don't 
you?" Sara said with a glowing smile that showed little sign of exhaustion from her eleven-hour work at the assembly line that day.

"Yes," I admitted hesitantly, "I'm here to learn." I was starting to realize through such exchanges that there was little room for the detached observer in my fieldwork among Brazilian Pentecostal converts in Japan. Since I could not be a fully immersed participant, either, in terms of what my informants called faith, my principle in dealing with my ambiguous insider/outsider status was honesty to the degree that it was appropriate. "Well," I blurted, "if I can be frank, Sara, I think it's a little bit strange."

"Oh?"

"When you say God is with you anytime, anywhere ... does that mean someone is by my side even when I'm sitting on a toilet? That feels ... weird."

Sara blinked and then burst out laughing. "It's not like that, Suma! God is a gentleman!"

By the time Sara and I hugged and said good night to each other, it was past midnight. I started driving, following the familiar signs for Route 155. Japan National Route 155 starts in Tokoname, Aichi, and continues counterclockwise in a large circle around the prefectural capital of Nagoya until it ends in Yatomi, Aichi. On the map, it is shaped almost perfectly like a question mark, with the Chübu Centrair International Airport located in the bottom dot. The airport on the artificial island serves as the entry point for most Brazilian migrants in the area, as well as the exit point for those who decided that their time in Japan was up. From Tokoname, where the airport is located, Route 155 stretches northward, eastward, and then westward, connecting many manufacturing cities in Aichi: Chita, Kariya, Chiryū, Toyota, and Komaki, to name a few. Toyota, located roughly halfway on the route, is home to the headquarters of the multinational automobile company, Toyota Motor Corporation. During my time there, I heard many residents comment matter-of-factly that the city was the powerful company's jōkamachi-a "castle town" whose virtual ruler was not in the city hall but in the headquarters building. In fact, it is the city that was named after the company, not the other way around. In 1959, then Koromo City passed a bill to officially change its name to Toyota City, making a gesture of appreciation to the corporation that brought in jobs, investments, and tax revenue.

My car had passed the city limit of Toyota, and soon enough I was driving on the part of Route 155 called Toyota Bypass, which was elevated to go over a vast Toyota plant. On both sides, I could see fields of gray steel buildings below, 
lit by colorful artificial lights and pumping out fuming smoke into the dark midnight sky. I wondered how many auto parts made by migrants such as Sara were transforming into brand-new cars at that moment. I also wondered absentmindedly how many Brazilian workers were on the night shift that night inside the factories that stood along the road.

Route 155, the big question mark. It was the artery of my fieldwork, bringing me to new places, people, and ideas. It led me to interviews in neighboring cities, to weekend barbecue parties on the seashore, and to new churches that my informants thought I should visit. Funny, I thought to myself, I'm chasing down the answers to my questions along this huge question mark. It hit me then that maybe it was not just me, the ethnographer, who was looking for some answers on this road. Some migrants came here in search of answers to their lives, typically what they called "the better future." To other migrants, such as Sara, the answer was now Jesus Christ, and their churches dotted the cities connected by the route. Many of us were on this big question mark, with our destinations uncertain and our quests unfinished.

The bypass ended and my car glided down, passing a large roadside sign that read "Welcome to Toyota, the City of Cars." "Almost there," I muttered to myself. "Almost home." 


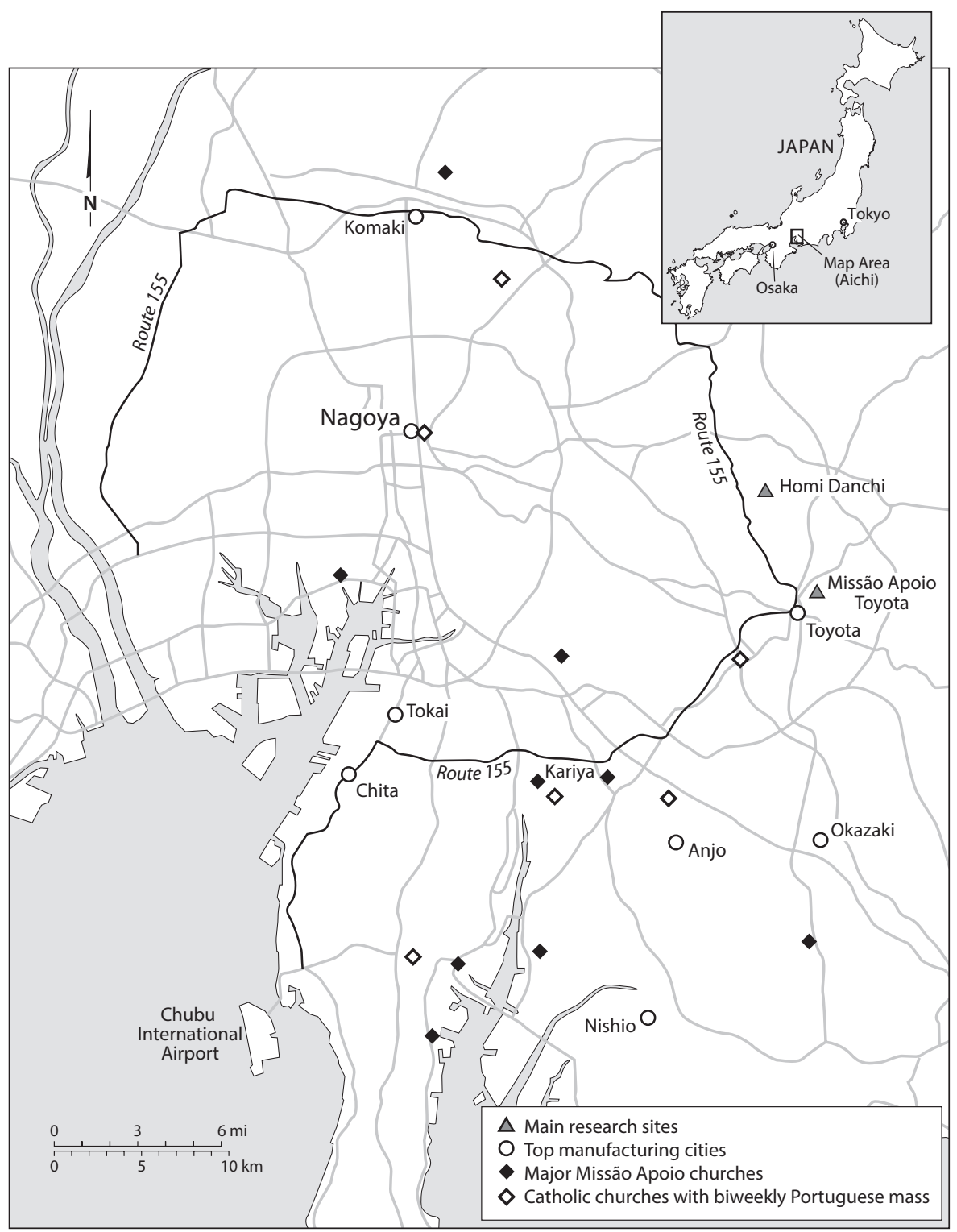

FIGURE 1. Map of the Aichi Prefecture, Japan, with Route 155 and research-related sites. 
JESUS LOVES JAPAN 
This page intentionally left blank 